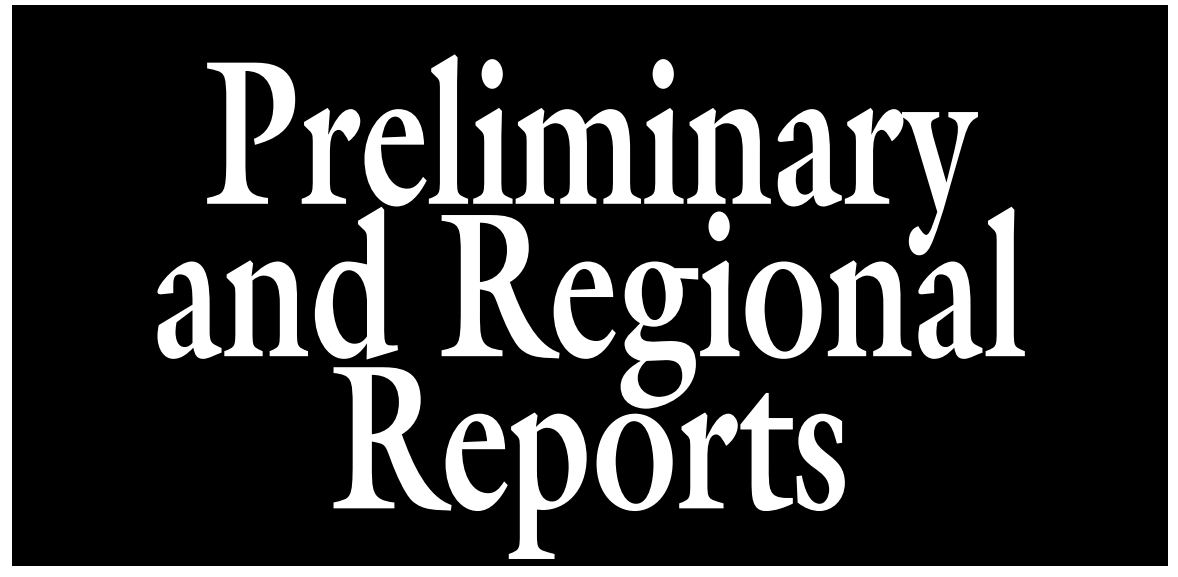

\section{Plant Growth Regulator Drenches Suppress Foliage and Inflorescence Height of 'Leia' Pineapple Lily}

\author{
Alicain S. Carlson' ${ }^{1}$, John M. Dole, and Brian E. Whipker
}

AdDitional index words. Eucomis, flurprimidol, paclobutrazol, Piccolo, Sumagic, Topflor, uniconazole

Summary. Plant growth regulators (PGRs) are used to control excessive plant growth in potted crops to improve quality and compactness for shipping and display. Pineapple lily (Eucomis sp.), a recent introduction to the potted crop market, can have excessive foliage growth and inflorescence height making the use of PGRs desirable. Bulbs of 'Leia' pineapple lily were forced in the greenhouse and drenched at leaf whorl emergence with three PGRs at five different concentrations: 1) flurprimidol $(0.25,0.5,1.0,2.0$, and $4.0 \mathrm{mg}$ per 6.5 -inch pot $), 2)$ uniconazole $(0.25,0.5,1.0,2.0$, and $4.0 \mathrm{mg} / \mathrm{pot})$, or 3$)$ paclobutrazol $(0.5,1.0,2.0,4.0$ and $8.0 \mathrm{mg} / \mathrm{pot}$ ) and an untreated control. As concentration increased, days to anthesis increased and foliage height decreased for each PGR. Paclobutrazol (4.0 and 8.0 $\mathrm{mg} /$ pot $)$, uniconazole $(4.0 \mathrm{mg} / \mathrm{pot})$, and flurprimidol $(2.0$ and $4.0 \mathrm{mg} / \mathrm{pot})$ treatments resulted in excessive stunting with none of the plants being marketable. Flurprimidol had the greatest influence on plant growth among all the PGRs. Acceptable concentrations for each PGR are paclobutrazol at 0.5 to $2.0 \mathrm{mg} / \mathrm{pot}$, uniconazole at 0.25 to $2.0 \mathrm{mg} /$ pot, and flurprimidol at 0.5 to $1.0 \mathrm{mg} /$ pot based on percentage of marketable plants and foliage and inflorescence height suppression without excessively increasing the number of days to anthesis.

$\mathrm{P}$ ineapple lily, a recent introduction to the potted crop market, grows from a true bulb forming a rosette of lanceolate leaves. From that rosette emerges a spike inflorescence lined with star-shaped florets and a terminal tuft of bracts making it resemble a pineapple, from which its common name is derived (Fig. 1).

Department of Horticultural Science, North Carolina State University, Campus Box 7609, Raleigh, NC 27695

We gratefully acknowledge funding by the Gloeckner Foundation, plant material from Golden State Bulb Growers, and support from the floriculture research technicians Ingram McCall and Diane Mays and research assistant Blair Lane.

${ }^{1}$ Corresponding author. E-mail: ascarlso@ncsu.edu.
The genus Eucomis contains about 15 species (Bryan and Griffiths, 1995) and many hybridized cultivars now exist that vary in color, scent, vigor, and hardiness. Typically, pineapple lily flowers in high light and heat during summer, but cultivars have been bred that will flower throughout the year (Meshorer, 2013).
The inflorescences of pineapple lily can also get very tall and bend during production (DeHertogh and Le Nard, 1993) and foliage can lengthen excessively, especially under low light, causing problems during shipping and handling. 'Leia' is a hybrid cultivar bred for compactness, multiflowering, and fragrance (Meshorer, 2013). While high light promotes naturally compact, sturdy plants (Meshorer, 2013), PGRs may be necessary during the low light levels of the winter months or under shade in high temperatures to promote similar compact sturdy plants. Minimal information has been published on the use of PGRs to control growth of pineapple lily, but Filios and Miller (2013) found paclobutrazol $(4.0$ and $8.0 \mathrm{mg} / \mathrm{pot}$ ) and flurprimidol $(2.0 \mathrm{mg} / \mathrm{pot})$ to be effective in controlling height of 'Innocence' and 'Tugela Ruby' pineapple lily (Eucomis comosa). Substrate drenches of flurprimidol have been effective at controlling plant height in several bulbous species, including calla lily [Zantedeschia aethiopica (Whipker et al., 2011b)], elephant ear (Caladium), daffodil (Narcissus), and oriental lily (Lilium hybrids) (Whipker et al., 2011a). Substrate drenches of flurprimidol and paclobutrazol did not affect flower height of amaryllis (Hippeastrum) and paclobutrazol and uniconazole reduced leaf length (Miller et al., 2013). Plant growth regulators may also limit postharvest stretching of leaves and inflorescences in low-light retail environments. Postharvest drenches of paclobutrazol on 'Leia' pineapple lily have enhanced postharvest shelf life to 5 to 6 weeks indoors and 8 to 10 weeks outdoors (Massey-Pratt, 2012). The objective of this study was to determine the effects of five concentrations of the PGRs flurprimidol, uniconazole, and paclobutrazol on growth and flowering of 'Leia' pineapple lily.

\section{Materials and methods}

Bulbs of 'Leia' pineapple lily were planted one bulb per 6.5-inch

\begin{tabular}{llll}
\hline $\begin{array}{l}\text { Units } \\
\begin{array}{l}\text { To convert U.S. to SI, } \\
\text { multiply by }\end{array}\end{array}$ & U.S. unit & SI unit & $\begin{array}{l}\text { To convert SI to U.S., } \\
\text { multiply by }\end{array}$ \\
\hline 29.5735 & $\mathrm{fl} \mathrm{oz}$ & $\mathrm{mL}$ & 0.0338 \\
2.54 & inch $(\mathrm{es})$ & $\mathrm{cm}$ & 0.3937 \\
28,350 & $\mathrm{Oz}$ & $\mathrm{mg}$ & $3.5274 \times 10^{-5}$ \\
1 & $\mathrm{ppm}$ & $\mathrm{mg} \cdot \mathrm{L}^{-1}$ & 1 \\
$\left({ }^{\circ} \mathrm{F}-32\right) \div 1.8$ & ${ }^{\circ} \mathrm{F}$ & ${ }^{\circ} \mathrm{C}$ & $\left({ }^{\circ} \mathrm{C} \times 1.8\right)+32$
\end{tabular}


pot in a commercial peat-based substrate (Fafard 4P; Fafard, Agawam, MA) and grown in a greenhouse at night/day set points of $60 / 75{ }^{\circ} \mathrm{F}$ starting 9 May 2012. On 25 June 2012, when the emerging leaf whorl was $\approx 5-\mathrm{cm}$ tall, each pot was drenched with $4 \mathrm{fl} \mathrm{oz}$ of flurprimidol (Topflor; SePRO Corp., Carmel, IN), uniconazole (Sumagic; Valent USA, Marysville, OH), or paclobutrazol (Piccolo; Fine Americas, Walnut Creek, CA) at concentrations of $0.25,0.5,1.0,2.0$, and $4.0 \mathrm{mg} /$ pot for flurprimidol and uniconazole and $0.5,1.0,2.0,4.0$ and $8.0 \mathrm{mg} /$ pot for paclobutrazol. This resulted in a $3 \times 5$ factorial ( 3 PGRs $\times 5$ concentrations) arranged in a completely randomized design with eight replications of each treatment combination. Each replication consisted of one pot containing one bulb. An untreated control was also included. Plants were fertigated during the week with 150 ppm nitrogen $(\mathrm{N})$ using premixed commercial 20N-4.4P-16.6K fertilizer (Peter's, Allentown, PA) when the substrate was dry, but the plant had not wilted. Clear water was used on weekends.

Days to visible bud (when the top bracts of the inflorescence were visible deep in the center of the rosette of

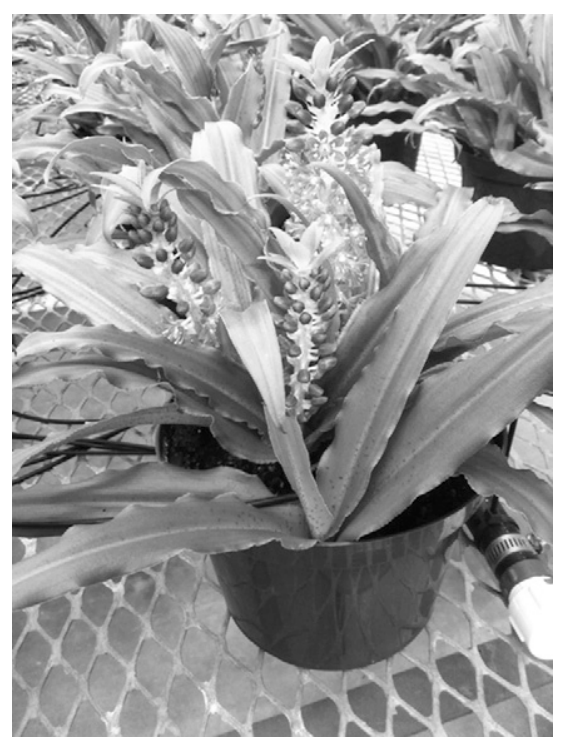

Fig. 1. Marketable plant of 'Leia' pineapple lily drenched with paclobutrazol at $0.5 \mathrm{mg}$ per 6.5 -inch $(16.51 \mathrm{~cm})$ pot. A plant was determined to be marketable if it reached anthesis with flowers and foliage that were at least $10 \mathrm{~cm}$ (3.9 inches) tall, had no inflorescence or foliage abnormalities, and inflorescences were not leaning past $45^{\circ} ; 1 \mathrm{mg}=3.5274 \times 10^{-5} \mathrm{oz}$. leaves) and anthesis (when the first row of florets opened on the inflorescence), were recorded. At anthesis, foliage and inflorescence height (from substrate to tallest point), plant diameter (two perpendicular measurements taken over the top of the plant), inflorescence stem caliper (measured
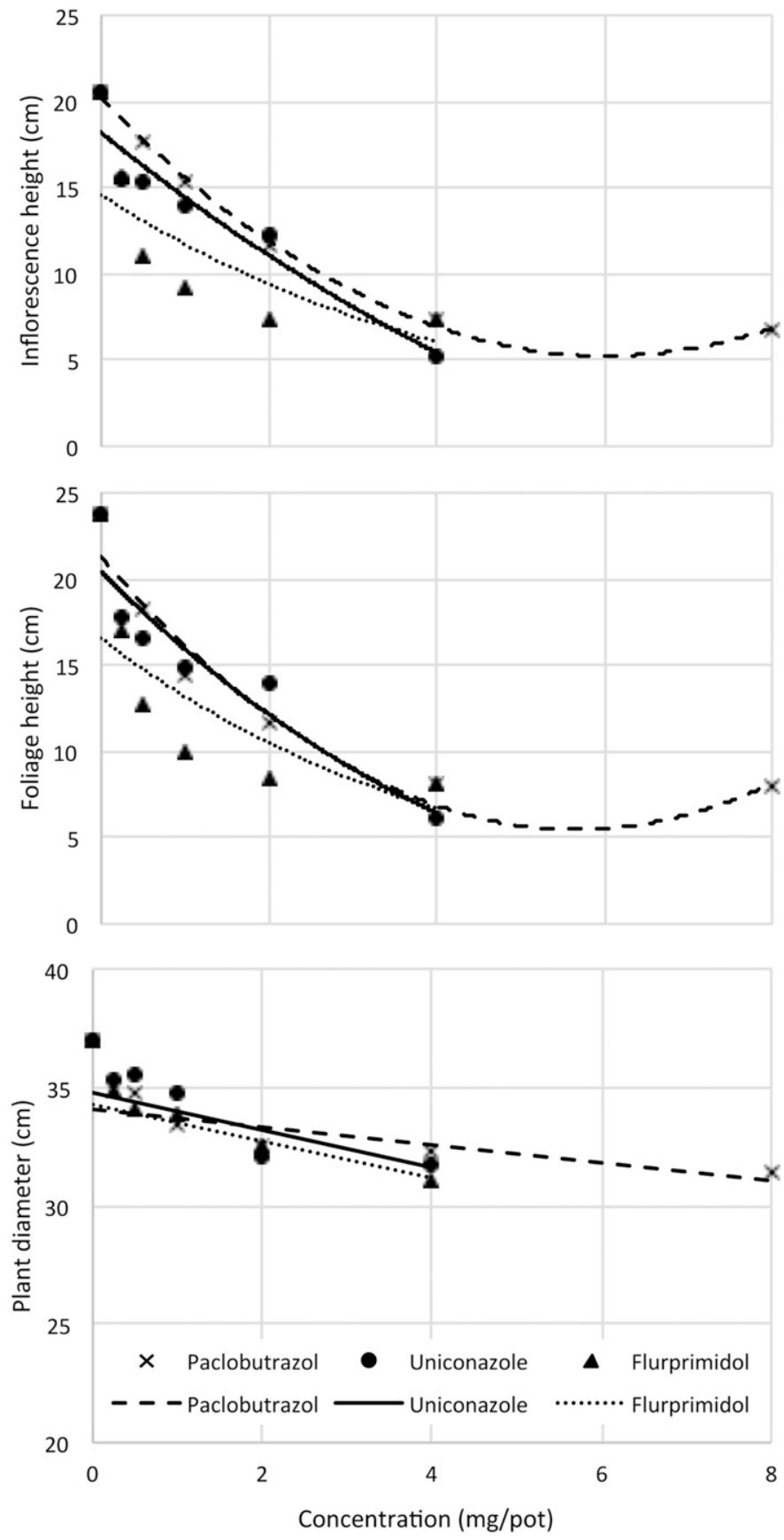

Fig. 2. Effects of paclobutrazol, uniconazole, and flurprimidol drenches at five concentrations $[0.25,0.5,1.0,2.0$, and $4.0 \mathrm{mg} /$ pot for flurprimidol, uniconazole, and $0.5,1.0,2.0,4.0$ and $8.0 \mathrm{mg} /$ pot for paclobutrazol] on 'Leia' pineapple lily grown in 6.5 -inch $(16.51 \mathrm{~cm})$ pots. An untreated control was also included. All measurements were taken at anthesis. Inflorescence height: paclobutrazol trend line $\left(y=0.42 x^{2}-\right.$ $\left.5.1 \mathrm{x}+20.2, R^{2}=0.82, P<0.0001\right)$, uniconazole trend line $\left(\mathrm{y}=0.17 \mathrm{x}^{2}-3.9 \mathrm{x}+18.2\right.$, $\left.R^{2}=0.74, P<0.0001\right)$, flurprimidol trend line $\left(\mathrm{y}=14.595 \mathrm{e}^{-0.22 \mathrm{x}}, R^{2}=0.63, P<\right.$ $0.0001)$. Foliage height: paclobutrazol trend line $\left(y=0.52 x^{2}-5.9 x+21.3, R^{2}=0.80\right.$, $P<0.0001)$, uniconazole trend line $\left(\mathrm{y}=0.35 \mathrm{x}^{2}-4.7 \mathrm{x}+20.4, R^{2}=0.74, P<0.0001\right)$, flurprimidol trend line $\left(\mathrm{y}=16.561 \mathrm{e}^{-0.227 \mathrm{x}}, R^{2}=0.64, P<0.0001\right)$. Plant diameter: paclobutrazol trend line $\left(\mathrm{y}=-0.37 \mathrm{x}+34.1, R^{2}=0.12, P=0.0007\right)$, uniconazole trend line $\left(\mathrm{y}=-0.83 \mathrm{x}+34.8, R^{2}=0.07, P=0.0216\right)$, flurprimidol trend line $\left(\mathrm{y}=-0.7 \mathrm{x}+34.3, R^{2}=0.13, P=0.0025\right) ; 1 \mathrm{mg}=3.5274 \times 10^{-5} \mathrm{oz}, 1 \mathrm{~cm}=0.3937$ inch. 
just below the floret cluster), number of inflorescences, and number of marketable plants were recorded. A plant was determined to be marketable if it reached anthesis with flowers and foliage that were at least $10 \mathrm{~cm}$ tall, had no inflorescence or foliage abnormalities, and inflorescences were not leaning more than $45^{\circ}$.

Statistical analysis. Data were tested by analysis of variance procedures using the general linear models procedure. Trend analyses were performed for days to anthesis and percentage of marketable plants. Foliage and inflorescence heights and plant diameters were regressed using regression procedures. Best fit was based on $R^{2}$ values. All analyses were performed using SAS (version 9.3; SAS Institute, Cary, NC).

\section{Results}

ALL PGRs. Regardless of the PGR used, as concentration increased, the final inflorescence height, foliage height, and plant diameter were increasingly reduced resulting in shorter and more compact plants (Fig. 2). For all three PGRs, the number of days to visible bud, number of flowers per pot, and inflorescence caliper were unaffected by concentration (data not presented). No phytotoxicity was noted for any of the PGRs at any concentration.

Paclobutrazol. A quadratic relationship occurred between days to anthesis and paclobutrazol concentration such that days to anthesis of plants drenched with $0.5,1.0$, or $2.0 \mathrm{mg} /$ pot was greater than that of control plants and less than that of plants drenched with 4.0 or $8.0 \mathrm{mg} /$ pot (Table 1). Percentage of marketable plants increased linearly as paclobutrazol concentration increased; however, increasing the concentration to 4.0 and $8.0 \mathrm{mg} /$ pot resulted in no marketable plants due to excessive stunting of the foliage and inflorescences (Fig. 3). Paclobutrazol at $0.5 \mathrm{mg} /$ pot offered several benefits by increasing percent of marketable plants by $25 \%$ and controlling foliage and inflorescence height by $23 \%$ and $15 \%$ compared with the control, respectively. However, the number of days to anthesis was increased by $18 \%$ compared with the control.

UniconAzOLE. A linear relationship occurred between days to anthesis and uniconazole concentration such that days to anthesis increased from $53.0 \mathrm{~d}$ for the control to $64.4 \mathrm{~d}$ as concentration increased to $4.0 \mathrm{mg} / \mathrm{pot}$
(Table 1). Percentage of marketable plants increased quadratically as uniconazole concentration increased from 0 to $2.0 \mathrm{mg} /$ pot; however, increasing the rate to $4.0 \mathrm{mg} /$ pot resulted in no marketable plants due to excessive stunting of the foliage and inflorescences. Uniconazole at 0.25 $\mathrm{mg} /$ pot only increased the days to anthesis by $7 \%(\approx 4 \mathrm{~d})$ from the control and reduced both foliage and inflorescence height by $25 \%$ as compared with the control. Additionally, the percent of marketable plants increased by $12 \%$ from the control.

Flurprimidol. A quadratic relationship occurred between days to anthesis and flurprimidol concentration such that days to anthesis of plants drenched with 0.25 or 0.5 $\mathrm{mg} /$ pot was greater than that of control plants and less than that of plants drenched with $1.0,2.0$, or 4.0 $\mathrm{mg} /$ pot (Table 1). Percentage of marketable plants increased linearly as flurprimidol concentration increased; however, increasing the concentration to 2.0 and $4.0 \mathrm{mg} /$ pot resulted in no marketable plants due to excessive stunting of the foliage and inflorescences. Flurprimidol at $0.5 \mathrm{mg} /$ pot increased the days to anthesis by $22 \%$ compared with the control and controlled foliage and inflorescence height by $54 \%$ and

Table 1. Effects of paclobutrazol, uniconazole, or flurprimidol drenches at five concentrations $[0.25,0.5,1.0,2.0$, and $4.0 \mathrm{mg} /$ pot for flurprimidol and uniconazole, $0.5,1.0,2.0,4.0$ and $8.0 \mathrm{mg} /$ pot for paclobutrazol] on days to anthesis and percentage of marketable plants on 'Leia' pineapple lily grown in 6.5 -inch $(16.51 \mathrm{~cm})$ pots. An untreated control was also included. A plant was determined to be marketable if it reached anthesis with flowers and foliage that were at least $10 \mathrm{~cm}$ tall, had no inflorescence or foliage abnormalities, and inflorescences were not leaning past $45^{\circ}(n=8)$.

\begin{tabular}{|c|c|c|}
\hline Concn $(\mathrm{mg} / \mathrm{pot})^{\mathrm{z}}$ & Time to anthesis from planting (d) & Marketable plants (\%) \\
\hline \multicolumn{3}{|c|}{ Paclobutrazol } \\
\hline 0.0 & 53.0 & 63 \\
\hline 0.5 & 62.6 & 88 \\
\hline 1.0 & 67.0 & 88 \\
\hline 2.0 & 66.6 & 88 \\
\hline 4.0 & 76.3 & 0 \\
\hline 8.0 & 81.0 & 0 \\
\hline Linear $^{y}$ & $<0.0001$ & $<0.0001$ \\
\hline Quadratic & 0.0031 & NS \\
\hline Residual & NS & $<0.0001$ \\
\hline \multicolumn{3}{|c|}{ Uniconazole } \\
\hline 0.0 & 53.0 & 63 \\
\hline 0.25 & 56.8 & 75 \\
\hline 0.5 & 58.8 & 63 \\
\hline 1.0 & 60.8 & 75 \\
\hline 2.0 & 63.0 & 75 \\
\hline 4.0 & 64.4 & 0 \\
\hline Linear & $<0.0001$ & 0.0014 \\
\hline Quadratic & NS & 0.0220 \\
\hline Residual & NS & NS \\
\hline \multicolumn{3}{|c|}{ Flurprimidol } \\
\hline 0.0 & 53.0 & 63 \\
\hline 0.25 & 65.0 & 50 \\
\hline 0.5 & 64.7 & 75 \\
\hline 1.0 & 68.2 & 63 \\
\hline 2.0 & 71.7 & 0 \\
\hline 4.0 & 73.0 & 0 \\
\hline Linear & $<0.0001$ & $<0.0001$ \\
\hline Quadratic & 0.0034 & NS \\
\hline Residual & NS & 0.0288 \\
\hline
\end{tabular}

${ }^{\mathrm{z}} 1 \mathrm{mg}=3.5274 \times 10^{-5} \mathrm{oz}$.

y Probability values were obtained using trend analysis procedures of SAS (version 9.3; SAS Institute, Cary, NC); NS = not significant. 

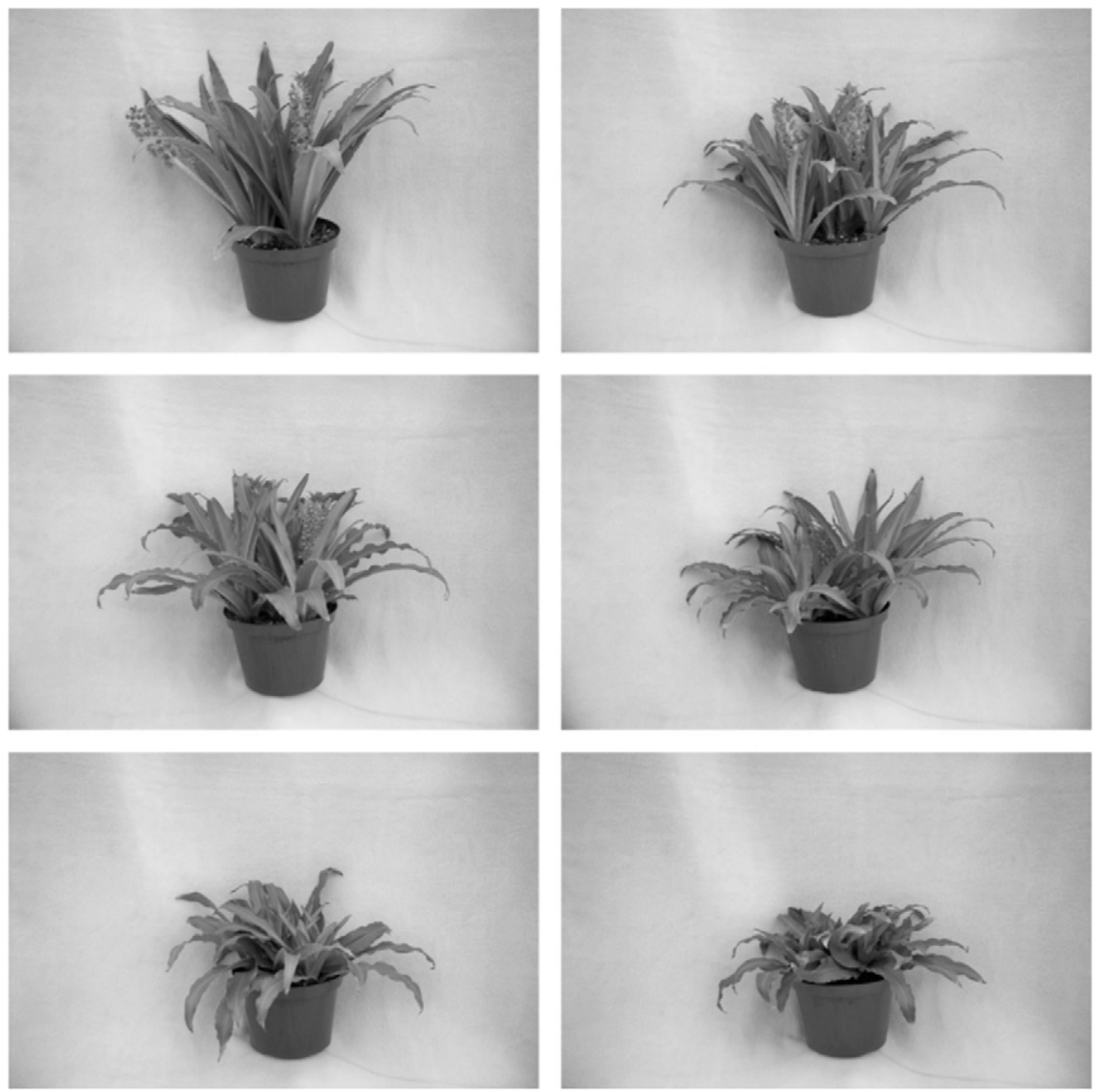

Fig. 3. Effects of paclobutrazol drenches at $0,0.5,1.0,2.0,4.0$, and $8.0 \mathrm{mg} / \mathrm{pot}$ on 'Leia' pineapple lily grown in 6.5 -inch $(16.51 \mathrm{~cm})$ pots. The 4.0 and $8.0 \mathrm{mg} / \mathrm{pot}$ concentrations severely stunted growth making plants unmarketable. A plant was determined to be marketable if it reached anthesis with flowers and foliage that were at least $10 \mathrm{~cm}$ (3.9 inches) tall, had no inflorescence or foliage abnormalities, and inflorescences were not leaning past $45^{\circ} .1 \mathrm{mg}=3.5274 \times 10^{-5} \mathrm{oz}$.

$47 \%$, respectively, as compared with the control. The percent of marketable plants increased by $12 \%$ from the control.

\section{Discussion}

Overall, each PGR suppressed inflorescence height more than foliage height. Acceptable concentrations for each PGR were: paclobutrazol at 0.5 to $2.0 \mathrm{mg} / \mathrm{pot}$, uniconazole at 0.25 to $2.0 \mathrm{mg} / \mathrm{pot}$, and flurprimidol at 0.5 to $1.0 \mathrm{mg} / \mathrm{pot}$ based on percentage of marketable plants and foliage and inflorescence height suppression without excessively extending days to anthesis. The highest concentrations of PGRs in these studies resulted in extreme reduction of the foliage and inflorescence growth causing the plants to be unmarketable. Flurprimidol had the greatest influence on plant growth among all the PGRs illustrated by the $54 \%$ suppression of foliage height at the lowest concentration $(0.25$ $\mathrm{mg} / \mathrm{pot}$ ) as compared with uniconazole at the same concentration, which suppressed height by $25 \%$ from the control.

Filios and Miller (2013) applied drenches of uniconazole at $0.1,0.25$, and $0.5 \mathrm{mg} /$ pot and found it ineffective in controlling foliage height of 'Innocence' and 'Tugela Ruby' pineapple lily. In contrast, we found 0.25 and $0.5 \mathrm{mg} /$ pot to effectively control plant height of 'Leia' pineapple lily. Paclobutrazol was effective at 4.0 and $8.0 \mathrm{mg} /$ pot and flurprimidol at 2.0 $\mathrm{mg} / \mathrm{pot}$ for 'Innocence' and 'Tugela Ruby' pineapple lily (Filios and Miller, 2013), whereas those rates severely stunted 'Leia' pineapple lily. Species/cultivar differences are likely the greatest factor in the difference in these responses (Whipker and Evans, 2011). 'Innocence' and 'Tugela Ruby' pineapple lily are E. comosa, which are naturally larger plants with greater growth as compared with 'Leia' pineapple lily, a hybrid of two unknown species, which was bred for its more compact nature (Meshorer, 2013).

The best application option, economically, would be to use the lowest effective concentration of PGR to suppress height to avoid unnecessary costs and waste, while considering the possibility of extra production time. 'Leia' pineapple lily can take 13 to 16 weeks to reach marketable size and 4 to 6 weeks from visible bud stage to anthesis (Meshorer, 2013), so PGR applications that significantly delay anthesis are not desirable. Uniconazole at $0.25 \mathrm{mg} /$ pot extended production time by about $4 \mathrm{~d}$, the least of all the PGRs used, which would be ideal for producers needing to control plant height and increase percentage of marketable plants, but are concerned about timing. A further increase in the percentage of marketable plants can be obtained with paclobutrazol at $0.5 \mathrm{mg} /$ pot with about $10 \mathrm{~d}$ of increased production time. A more pronounced difference in the percentage of marketable plants between the untreated and treated plants that were not severely stunted could be obtained with plants grown under lower light conditions. This study was conducted in the summer months when light levels are naturally high causing a lack of unmarketable plants in the control that had inflorescences that were tall enough to bend over. Most of the untreated plants that were not marketable did not flower.

The benefits of using PGRs on 'Leia' pineapple lily likely depend on the growing conditions and postharvest environment. 'Leia' pineapple lily grown with night temperatures lower than $60{ }^{\circ} \mathrm{F}$ results in more compact plants (Correiar, 2014). Sometimes these low night temperatures are not always possible so growth regulators can help prevent elongation from higher temperatures. Production under low light levels during the winter months results in increased height so PGRs would be useful for growers producing 'Leia' pineapple lily under less than optimal light levels for holiday sales such as Mother's Day and Valentine's Day. Plant growth regulators may also help reduce stretch when plants are grown closer together to use production space most efficiently. Plant growth regulators 
may limit postharvest stretching of leaves and inflorescences in low-light retail environments. Postharvest drenches of paclobutrazol on 'Leia' pineapple lily have enhanced postharvest shelf life to 5 to 6 weeks indoors and 8 to 10 weeks outdoors (Massey-Pratt, 2012). Knowing these effective concentrations will help growers determine options for chemicals and concentrations to produce high quality, marketable plants in less than optimal growing conditions.

\section{Conclusion}

The tested PGRs were effective in suppressing foliage and inflorescence height and slightly increasing the percentage of marketable plants of potted 'Leia' pineapple lily when applied at leaf whorl emergence. Acceptable concentrations for each PGR are paclobutrazol at 0.5 to 2.0 $\mathrm{mg} / \mathrm{pot}$, uniconazole at 0.25 to 2.0 $\mathrm{mg} / \mathrm{pot}$, and flurprimidol at 0.5 to $1.0 \mathrm{mg} /$ pot based on percentage of marketable plants and foliage and inflorescence height control without excessively extending the number of days to anthesis. From this research growers can select a PGR suited for their production situation to suppress foliage and inflorescence height and increase the number of marketable plants, while balancing the potential increase in production time.

\section{Literature cited}

Bryan, J. and M. Griffiths. 1995. Manual of bulbs. Timber Press. Portland, OR.

Correiar, B. 2014. Aloha lily Eucomis: Tropical color and fragrance year-round. 1 Oct. 2014. <http://www.ballpublishing. com/growertalks/ViewArticle.aspx?articleid= 20980>.

De Hertogh, A. and M. Le Nard. 1993. The physiology of flower bulbs. Elsevier, Amsterdam, The Netherlands.

Filios, P.M. and W.B. Miller. 2013. Effects of flurprimidol, paclobutrazol, and uniconazole drenches on Eucomis comosa growth. Acta Hort. 1002:439-443.

Massey-Pratt, N. 2012. Eucomis 'Aloha Lily Leia’ Greenhouse Prod. News 22(8):5659.
Meshorer, N. 2013. Eucomis aloha lily series. Greenhouse Prod. News 23(11):4849.

Miller, C.T., C.M. Filios, and W.B. Miller. 2013. Effects of flurprimidol, paclobutrazol, and uniconazole soaks and drenches on amaryllis (Hippeastrum) growth and development. Acta Hort. 1002:431-438.

Whipker, B.E. and M.R. Evans. 2011. Regulation of plant growth, p. 373-390. In: P.V. Nelson (ed.). Greenhouse operation and management. 7th ed. Pearson, New York, NY.

Whipker, B.E., B. Krug, I. McCall, and W. Buhler. 2011a. Flurprimidol preplant soaks and substrate drenches control excessive plant growth. Acta Hort. 886:383-389.

Whipker, B.E., I. McCall, and W. Buhler. 2011 b. Control of calla lily growth with flurprimidol preplant tuber soaks and substrate drenches. Acta Hort. 886:395-398. 